\title{
Transition Action Details (Tad) Strategy in Teaching Writing Recount Text
}

\author{
Siti Yulianti ${ }^{1}$, Dwi Andriani ${ }^{2}$ and Zulaikah ${ }^{3}$ \\ Pendidikan Bahasa Inggris STKIP Nurul Huda Sukaraja \\ 1sitivulianti3101@gmail.com
}

\begin{abstract}
This thesis is entitled "The Use of Transition Action Details Strategy in Teaching Writing Ability to the Eighth Grade Students of SMP Muhammadiyah 1 Rawabening". The objective of this study was to know whether or not there are any significant differences between the student who are taught by using the Transition Action Details Strategy and the student who is not taught by using it. This study used an experimental method, a quasi -experimental design. The population of this study was 47 students, and the sample was 47 students was taken by using purposive sampling, those were 24 students of the experimental group and 23 students of the control group. Based on the calculation by using an independent t-test by using SPSS 16, The writer found that t-obtained was higher than t-table $(2.868>2.014)$ at the significant level $\mathrm{a}=0.05$ in two-tailed testing. It meant that there were any significant differences between the experimental group and the control group. So, the null hypothes is $(\mathrm{Ho})$ was rejected and alternative hypotheses $(\mathrm{Ha})$ were accepted. It can be concluded that Transition Actions Details Strategy was significant in teaching writing ability to the eighth-grade students of SMP Muhammadiyah 1 Rawabening.
\end{abstract}

Keywords: Writing, Transition Action Details Strategy, Recount text

\section{INTRODUCTION}

In human life, language is one important thing. Because, "we use language in every life" (Dalilan, 2010: 1). People can express their ideas and feelings by using language. Besides, language allows people around the world to interact and connect. One of the important languages in the English language. The reason for English is important because it is an international language (Brown, 2000: 181). Apart from being an international language, " English is also a global language" (Crystal, 2003: 1) ". This is a reason that the Indonesian government chooses English as the first foreign language to be taught in the school of Indonesian. As a foreign language, English has four skills that have to be mastered by the students. The four skills include listening, speaking, reading, and writing ( Littlejohn,2005: 88).

One of the important skills is writing skills. Writing, as a means of developing students' general abilities in English, is greatly undervalued in most language courses. In this case, writing became the focus of classroom work. In writing, it also requires skills." Writing skills are a development process that requires opportunities, experience, training, ideas in an interesting and clearly organized manner" (Taqi, 2015: 74). It can be concluded that in English language writing is very important.

Based on the interview with an English teacher (his name is Meydi Hartanto, B.A) of SMP Muhammadiyah 1 Rawabening, the writer found out some difficulties in the students' writing ability. The difficulties include that students do not understand how to start writing in English, students cannot make good sentences when writing a text, and they always think that making good writing in English is very difficult. Another cause is grammar, vocabulary, spelling, and punctuation marks.

From the descriptions above, the writer is interested to investigate the teaching of writing ability, especially using the Transition Action Details (TAD) Strategy whether it can help the students' writing ability. According to Nui (2013: 48), described that Transition Action Details Strategy help student to remember or to add more transition and details to their writing. By using this strategy students can retell their experience in organizational planning. So, students can develop their ideas logically and completely. Moreover, Manurung (2013: 5) explains that the Transition Action Details Strategy was suitable to be used for students in writing recount text. It can be proven by student's activities during this learning process. 


\section{Concept of Writing}

Writing is a process of expressing thoughts in writing that have a specific purpose. The purpose of this writing process is to entertain, give information, or to persuade. One of the results of this writing process is usually called an article or essay in written form. According to Siahaan (2008: 2) said that writing is one of the abilities of a writer to provide information about a thought or idea and opinion in writing to readers.

Moreover, Hyland (2009: 191), says that writing is one of the fundamental things that modern society does that can transcend meaning in all of our lives. Some people think that writing is a product or an activity that everyone can learn independently. Writing is related to the ability to compose letters, then into words and sentences so that it becomes a language that can be used to communicate in writing. So, readers know the information contained in the writing.

From the definitions above, it can be summarized that writing is producing words from the author's mind through paper or other media.

\section{Concept of Recount Text}

Knapp (2005: 224) said that recount text is a text written to report an event or event that has happened in the past. This text aims to provide information about an event or to entertain people. Besides, Siahaan and Sianoda ( 2008: 9), said that the social function of recount text is to tell an event that has happened in the past and aims to provide information about an event or to entertain readers. This text tells about all of the events. Also, this text tells about what happened at that event and when it happened.

Based on the explanation above, the writer concluded that recount text is a text that tells about events that have occurred in the past. The purpose of this text is to retell an incident or event from the past with the intention that the reader is entertained when reading the text.

\section{Concept of Transition Action Details (TAD) Strategy}

Peha ( 2003: 38), said that the Transition Action Details Strategy is a writing strategy that used columns and rows to show a sequence of events. In this strategy, three columns must be filled by students, namely the transition column, action column, and details column. The action column was filled with things that happened in that event. Next to the detail column. This details column contains a description of the action column. The purpose of this column is to support the action column. Then, the final step is to create a simple phrase in the transition column that initiates each action. Also, According to Lester (2006: 62) states that TAD strategy has three steps;

1. Transitions

These steps contain simple words or phrases that help or introduce each new action in a sequence. The transition can help write them so that events can be structured in detail.

2. Actions

In action contains events or things that happened.

3. Details

This column contains additional information on each action. This column can support the action column.

Moreover, Julie Bumgardner (2011) said that Transition Action Details is a good strategy when we will convey information in a certain order. In this strategy, there are 3 parts, namely; transition, action, and details.

From the descriptions above, the writer concluded that Transition Action Details (TAD) strategy is one of the strategies in writing English, especially in writing recount text which consists of threecolumn, that is transition column, action column, and details column. 


\section{METHODOLOGY}

In this study, the writer used quantitative research. Quantitative research has two methods commonly used, namely the survey method and experimental method. In this study, the writer used the experimental method. Moreover, Sugiyono (2011: 73) stated that in the experimental method there where has four designs, that are pre-experimental, true-experimental, factorial design, and quasi-experimental design. Of the four designs in this study, the writer chose a quasi-experimental design.

In this study, the sample consisted of two classes, that is control class and experimental class. Because two classes have the same problem. So, the material and topic given are the same. The experimental group is taught by using the Transition Action Details (TAD) Strategy. Before the treatment, a pretest is given to both groups. After treatment, the posttest of the instrument is given to them. It can compare the students 'abilities in the experimental group and control group.

One of the important guidelines in conducting research is the existence of a variable. there were two variables, namely dependent variable and independent variable. The dependent variable was writing and the independent variable was Transition Action Details (TAD) Strategy. Also, the population is all the eighth graders of SMP Muhammadiyah 1 Rawabening with the total number of the population are 47 students consisting of 2 classes, the writer choose purposive sampling to determine sample from the 2 classes of the eighth graders of SMP Muhammadiyah 1 Rawabening and the total number of the sample of the study was 47 .

Also, to determine the students' ability in writing recount text, a written test was used as an instrument. And for analyzing the data by using an independent t-test.

\section{RESULT AND DISCUSSION}

The writer gave a pretest for the experimental and control group before conduct the treatment, and then calculated the students' score. There are meetings for treatment to the students by using Transition Action Details (TAD) Strategy in Teaching writing recount text, then the writer gave a posttest which is intended to know whether there are any significant differences between experimental and control group.

In this part, the writer presents the findings of the study that was already done findings highlight the result normality, homogeneity, and hypotheses that were taken during the research. It is shown in table 1.

Table 1

The Result of Normality, Homogeneity and Independent t-test

\begin{tabular}{|c|c|c|c|c|c|c|}
\hline & \multicolumn{6}{|c|}{ Statistical Analysis } \\
\hline & \multicolumn{2}{|c|}{ Normality } & \multirow{2}{*}{\begin{tabular}{|c} 
Homogeneity \\
Levene
\end{tabular}} & \multirow[t]{2}{*}{ Sample } & \multicolumn{2}{|c|}{ Independent t-test } \\
\hline & $\begin{array}{l}\text { Kolmogorov- } \\
\text { Smirnov }\end{array}$ & Shapiro & & & Ha & Ho \\
\hline TAD_Strategy & ,200 & ,101 & & & ,006 & \\
\hline Conventional_Strategy & ,196 & ,244 & 472 & 47 & $\begin{array}{c}\text { Accepte } \\
\text { d }\end{array}$ & \\
\hline
\end{tabular}

\section{CONCLUSION}

Based on table 1, it can be summary that there were any significant differences between the students who are taught by using Transition Action Details (TAD) Strategy and the students who are not taught by using Transition Action Details (TAD) Strategy in teaching writing ability to the eighth graders of SMP Muhammadiyah 1 Rawabening. It could be seen based on the result of the 
calculation of the Independent t-test of the posttest score in the Experimental and Control group $(0.006<0.05)$. From the data, it was also found that the students can reduce their problem in writing since the Transition Action Details (TAD) Strategy is applied in their classroom. By using the Transition Action Details (TAD) Strategy, one of the strategies that can solve their problem of writing was the Transition Action Details (TAD) Strategy, because Transition Action Details (TAD) Strategy was a good strategy to get a better understanding of the material.

\section{REFERENCIES}

Brown, H.D. (2000). Principles of Language Learning and Teaching (the fourth (2000) edition). New York: Pearson Education Company.

Bumgardner, J. (2011) .http: www. The word factory.com/2011/01/20/clearer directions-better-repost.acessed on july 28 .

Crystal, D. (2003). English As A Global Language. Cambridge

Dalilan. (2010). Text Introduction to Linguistic (Course Material). Unpublished Paper.Muhammadiyah University, Palembang.

Hyland, K. (2009). Researching Writing. Hongkong: City University.

Knapp, P., Watkins, M. (2005).Genre, Text, Grammar: Technologies for teaching and assessing writing. Sydney: University of New South Wales Press.

Lester, (2006). Be a Better Writer. Amerika, UK: LeverageFactory, Inc.

Manurung, C.D. (2013). Improving the Students' Achievement in Writing Recount Text by Using Transitions-Action-Details (TAD) Strategy. Medan, Indonesia.

Nui,K.M. (2013). Writing Resource Guide, Learning to Write. Honolulu :University of Hawai.

Peha, S. (2003). The Writing Teachers' Strategy Guide. New York :TTMS, inc.

Siahaan, S. (2008). The English paragraph (the first edition). Yogyakarta: Graha IImu.

Sugiyono. (2011). Metode Penelitian Pendidikan. Bandung: Alfabeta.

Taqi, Hanan A. et al. (2015). The Effect of Diary Writing on EFL Students' Writing and Language Abilities.UK: British Journal of Education, III (2) 75-91. Retrieved on Saturday, February 3rd, 2018. 